\title{
A Quantitative Estimate of the Peripheral Glomerular Basement Membrane in Recent Juvenile Diabetes
}

\begin{abstract}
By
Ruth ØSTERby Hansen

From the University Institute of Pathology (Head: Stewn OLSE, M. D.), Kommunehospitalet, Århus, Denmark, and the Second University Clinic of Internal Medicine (Head: K. LUNDBжK, M. D.), Kommunehospitalet, Arhus Denmark

Received July 19, 1965

Summary. A quantitative study of electron micrographs prepared from renal biopsies in 7 young patients with recent diabetes mellitus and from 3 non-diabetics is presented. In all the diabetic patients a biopsy was taken before treatment and after the normalization of the metabolic state. Basement membrane thickness was measured at constant intervals on montages of glomerular cross sections. The actual number of measurements varied between 438 and 1745 for each glomerulus. Frequency distribution curves of basement membrane thickness were similar in diabetics and non-diabetics. No difference was found between the results obtained in the first and the second biopsy in the diabetic patients. It is concluded that there is no thickening of the peripheral glomerular basement membrane in recent juvenile diabetes.

Résumé. Il a été fait une étude en microscopie électronique des glomérules de 7 jeunes sujets souffrant d'un diabète sucré récent et de 3 non-diabétiques. Chez tous les diabétiques les ponctions-biopsies du rein ont été faites aussi bien avant le commencement du traitement qu'après la normalisation de l'état métabolique. L'épaisseur de la membrane basale a été mesurée à intervalles constants sur des montages de coupes transversales de glomérules. Le nombre de mesures dans chaque cas parti-

culier a varié entre 438 et 1745 . Concernant l'épaisseur de la membrane basale les courbes de distribution de la fréquence ont été égales chez les diabétiques et les nondiabétiques. On n'a pas trouvé de différences entre les résultats donnés par la première et la deuxième biopsie On peut en conclure qu'il n'y a pas d'épaississement de la membrane basale périphérique glomérulaire dans un diabète juvénile récent.

Zusammenfassung. Eine elektronenmikroskopische Untersuchung von Nierenpunktionsbiopsien bei 7 jungen Diabetikern und bei 3 Kontrollpatienten ist durchgefiuhrt worden. Die Biopsie wurde bei den Diabetikern sowohl vor der Behandlungseinleitung als auch nach der Normalisierung der Glucosemetabolismus ausgeführt. Die Dicke der Basalmembran wurde mit konstanten Intervallen auf Glomerulus-Querschnitten gemessen. Die Zahl der Messungen variierte bei den verschiedenen Glomeruli zwischen 438 und 1745. Die Resultate wurden als Frequenzdiagramme aufgeführt. Die Diagramme waren bei Diabetikern und Kontrollpatienten gleich. Es wurde kein Unterschied zwischen der ersten und der zweiten Biopsie bei den Diabetikern gefunden. Es muß also gefolgert werden, daß keine Verdickung der peripherischen GlomerulusBasalmembran bei frischem, juvenilem Diabetes vorhanden ist.
\end{abstract}

Diabetic angiopathy is known to develop slowly over the years. Clinically it usually becomes manifest only after ten or more years of diabetes.

A new perspective in the discussion of vascular disease in diabetes mellitus has been opened during the last few years by several reports of changes in the capillary basement membrane in recent diabetes.

These reports include electron microscopic studies of the glomerular capillaries. Altogether, some twenty cases of juvenile diabetes of less than one year's duration have been studied by different groups of investigators. Furthermore, a few cases of "prediabetes" have also been studied. Glomerular abnormalities were described in most of these patients. Some authors have stressed the presence of a thickening of the peripheral basement membrane (GoETz et al., 1960, SABOUR et al., 1962, Bloodworth, 1963, Azírad et al., 1964, and MacDonald and Ireuand, 1964) while others have emphasized that the primary lesion is in the mesangial region (MÉrIEL et al., 1962, FIASCHI et al., 1963, Camerini-Dávalos et al., 1964). Actual measurements of the basement membrane have been carried out by some of these authors (GowTz et al., 1960,
Bloodworth, 1963, Rosenbaum et al., 1963 and MacDonald and TreLAND, 1964).

The present report presents the results of a quantitative study of the peripheral glomerular basement membrane in 7 newly discovered juvenile diabetics and in 3 non-diabetics.

\section{The Patients}

The patients had not received anti-diabetic therapy, except for case No. 6 who had been put on a "free diet without sugar" eight months prior to admission. The age of the patients, the duration of diabetes and the diabetic state as well as the diagnosis of the control cases appear in the Table.

None of the controls had glycosuria. The glucose tolerance test was normal in case No. 8 and No. 10. It was not performed in case No. 9 .

Renal function - as estimated by endogenous creatinine clearance - was normal in all the diabetics and in 2 of the controls (cases No. 8 and No. 10). In case No. 9 no clearance study was performed; however, there was no proteinuria. 
Table

\begin{tabular}{c|cccccccc}
\hline Case no. & age & sex & $\begin{array}{c}\text { Duration of } \\
\text { diabetic symp- } \\
\text { toms, months }\end{array}$ & $\begin{array}{c}24 \text { hrs urine glucose, gram* } \\
\text { at 1st biopsy }\end{array}$ & \multicolumn{2}{c}{$\begin{array}{c}\text { fasting blood glucose, mg\%** } \\
\text { at 2nd biopsy }\end{array}$} & at 1st biopsy & at 2nd biopsy \\
\hline 1 & 18 & M & 1 & 303 & 0 & 318 & 117 \\
\hline 2 & 25 & M & 3 & 112 & 0 & 252 & 89 \\
\hline 3 & 16 & F & 1 & $60 * * *$ & 0 & $207 * * *$ & 106 \\
\hline 4 & 32 & M & $12 ?$ & 115 & 5,7 & 211 & 65 \\
\hline 5 & 19 & M & $3 / 4$ & 102 & 2 & 237 & 93 \\
\hline 6 & 21 & M & 12 & 253 & 12 & 255 & 129 \\
\hline 7 & 13 & F & $3 / 4$ & 132 & 1.0 & 274 & 94 \\
\hline
\end{tabular}

cause of admission

\begin{tabular}{l|llll}
8 & 19 & M & cholelithiasis \\
\hline \multirow{2}{*}{} & 9 & 31 & M & cerebral hæmorrhage \\
\hline 10 & 12 & M & subacute appendicitis \\
\hline
\end{tabular}

\section{Methods}

A renal biopsy, using the technique of IvERSEN and BRUN (1951) in a later modification (BRUN and RAAsCHOU (1958), was performed on the diabetic patients before any therapy was given and it was repeated again after 3-6 weeks of vigorous treatment in hospital with diet and insulin.

In cases No. 8 and 10 needle biopsy was taken from the exposed kidney through the peritoneum at laparotomy. Case No. 9 was a donor for renal transplantation, and here a slice was taken from the renal cortex immediately after death.

Tissue for light microscopy was embedded in paraffin, while tissue for electron microscopy was fixed for one hour in $1 \% \mathrm{OsO}_{4}$ buffered in veronal-acetate to pH 7.3, dehydrated in acetòne and embedded in Vestopal W.

A small pyramid containing a single glomerulus at its top was prepared from each plastic-embedded block. Care was taken to obtain complete glomeruli. Thin sections were picked up on No. 100 copper grids. A total glomerular cross section can be contained in one square of such grids. The sections were photographed with a Philips EM 200, and the entire cross section of a glomerulus was mapped. Primary magnification was 1400 ; prints were processed with a ten-fold enlargement. The magnification of the microsope was checked for each glomerulus by photographing a carbon-grating replica grid.

The micrographs $(50-100$ in number) were fitted together to form a montage, producing a picture which

\footnotetext{
* average of 3 days before biopsy ( $p$-toluidin).

** average of 3 days before biopsy (Hagedorn-Norman Jensen).

*** on the day of biopsy.
}

represented the entire cross section of a single glomerulus.

Measurements were made at intervals of $0.5 \mu$ along the entire length of the peripheral basement membrane where the section was perpendicular to the basement membrane. The "peripheral basement membrane" is considered as that part which is beyond the first endothelial pore starting at the mesangial region. A section was only regarded as being perpendicular to the basement membrane when the limiting endothelial and epithelial cytoplasmic membranes were both distinet. If a measuring point was arrived at which did not fulfill this criterion, the basement membrane was then searched for a point where it did so.

The number of measurements thus defined varied between 438 and 1745 in each glomerular section with an average of 860 in diabetics and 1043 in controls. The low figure of $\mathbf{4 3 8}$ is from case No. one's first biopsy, in which only about a third of one glomerular cross section was available. Complete cross sections were obtained in the remaining glomeruli, except in 3 cases in which small areas representing up to about $10 \%$ of the section were missing.

In the first nine glomeruli studied, the thickness of the basement membrane was measured by placing a piece of graph paper over the basement membrane which allowed an accuracy of 0.5 millimeters, or 357 Angström. However, in the next eight glomeruli pointed-leg calipers, calibrated at 0.1 millimeter were used.

\section{Results}

On light microscopy all of the patients but one were found to have normal renal tissue. In case No. 4 it was felt that there might be a slight increase in the PAS-positive material in the mesangial regions. 

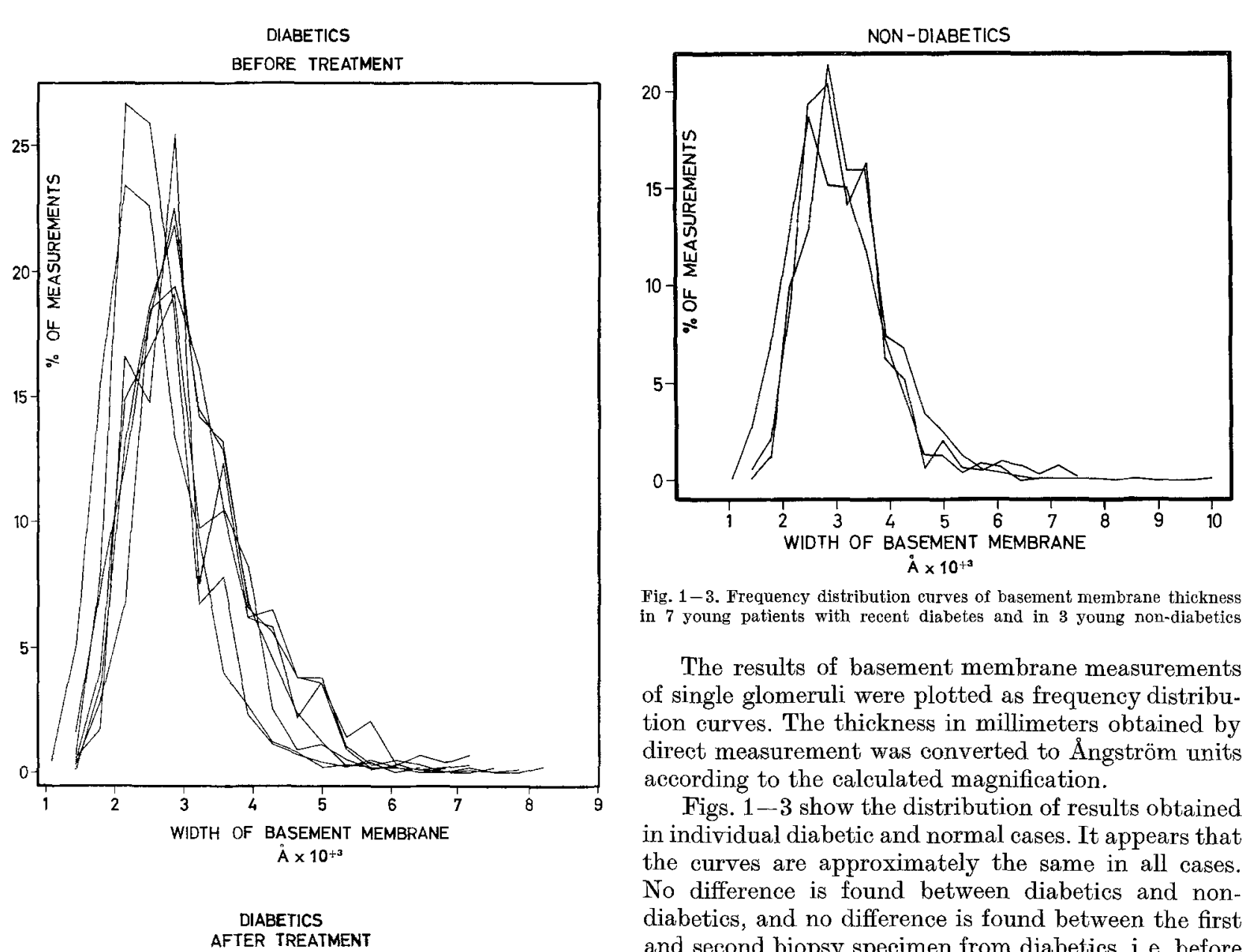

Fig. 1-3. Frequency distribution curves of basement membrane thickness in 7 young patients with recent diabetes and in 3 young non-diabetics

The results of basement membrane measurements of single glomeruli were plotted as frequency distribution curves. The thickness in millimeters obtained by direct measurement was converted to Angström units according to the calculated magnification.

Figs. $1-3$ show the distribution of results obtained in individual diabetic and normal cases. It appears that the curves are approximately the same in all cases. No difference is found between diabetics and nondiabetics, and no difference is found between the first and second biopsy specimen from diabetics, i. e. before and after normalization of the metabolic state.

The modal values in these cases vary from $2140 \AA$ to $2860 \AA$ in diabetics and from $2500 \AA$ to $2860 \AA$ in controls. As expected, the mean values are somewhat larger than the modal ones due to the shape of the curves. The few high values found in all cases are partly due to focal thickenings found both in diabetics and non-diabetics.

\section{Discussion}

The results of the present study differ from those obtained in earlier published studies, but this might be due to technical differences.

The idea of using total cross sections in the present study was to omit bias in the selection of areas for photography as well as in the choice of measuring points.

GoETz et al. (1960), in a short abstract, presented ranges of basement membrane thickness in 2 young, recent diabetics. No details of measurements are given, and thus comparison with the present study is not possible.

Sabovr et al. (1962) reported a study based on renal biopsies from 4 young, insulin-treated patients with a duration of diabetes of less than two years. They found that the mean value of basement mem- 
brane thickness varied between 4000 and 6000 Ångström units, however, no information is given as to how these values were obtained.

Later (1964) MacDonald and Ireuand from the same laboratory published new measurements obtained from glomeruli from 2 of these patients and from one new case as well as from 5 controls. In the three diabetic patients they found an average basement membrane thickness of 2416,2980 and $3033 \AA$ in the three cases, based on 50-100 measurements in each case. In the 5 controls the average values were between 1400 and $2700 \AA$. They conclude that in some cases of recent juvenile diabetes, thickening of the basement membrane is present.

Their average values for diabetic patients do not differ from ours; however, some of their control values are smaller than ours. No information is available, however, concerning selection of measuring points.

ROSENBAUM et al. (1963) reported rather high average values for basement membrane thickness in 2 of 3 children with recent diabetes, but their mean values were based on only a few measurements.

As mentioned above some authors feel that the primary lesion in diabetic glomeruli is in the mesangial region. The elucidation of this question requires quantitative studies.

Still many problems regarding the glomerular basement membrane remain to be solved. In the present study only a single cross section from a single glomerulus from each biopsy was used for measurement. We do not yet know if one section is truly representative of the whole glomerulus, or whether one glomerulus can be accepted as representative in any single patient.

However, the uniform results obtained in these 14 biopsies make it reasonable to conclude that there is no thickening of the peripheral glomerular basement membrane in recent, juvenile diabetics.

This study was supported by grants from "Statens Almindelige Videnskabsfond", the Novo Foundation and Michaelsen Fonden.

\section{Acknowledgments}

My thanks are due to civil engineer, Mr. A. BIRCHANDERSEN for valuable advice during this work.
I am also indebted to Dr. G. GREGERSEN for performing the kidney biopsies and to Drs. V. Posborg Petersen, O. FJeldiorg and H. SkJoldborg, Àrhus Kommunehospital and to Dr. B. MøLLER, Roskilde Hospital, for providing some of the biopsy material.

The skilful technical assistance of Miss Bente MartLEV and Mrs. BIRTHE IVERSEN is gratefully acknowledged.

\section{References}

AzÉRad, E., J. LubetzkI, J.C. Morard and P. SAMarcQ: Étude en microscopies optique et électronique de 56 fragments de reins diabétiques prélevés par ponctionbiopsies: fréquence et précocité des altérations glomérulaires. Le Diabète, 12, 163-169 (1964).

Bloodworth, J.M.B., Jr.: Diabetic Microangiopathy. Diabetes 12, 99-114 (1963).

BruN, C., and F. RaAschou: Kidney Biopsies. Am. J. Med. 24, 676-691 (1958).

Cameriny-Dávalos, R.A., J.B., Caulfield, S. B. Rees, O. Lozano-Castaneda, S. Naldjian and A. Marble: Preliminary Observations on Subjects with Prediabetes. Diabetes 12, 508-518 (1963).

Fiaschi, E., L.A. Scuro, R. Naccarato, G. Monti, G. Serpi and F. Sirigu: Intorno alle prime alterazioni morfologiche del rene nel diabete giovanile recente. Minerva Nefrologica 10, 95-108 (1963).

Goetz, F.C., J.F. HaRtManN and A. Lazarow: Electron Microscopy of the Human Glomerulus in Early Diabetes. J. Clin. Invest. 39, 991 (1960)

Iverser, P. and C. Brur: Aspiration Biopsy of the Kidney. Am. J. Med. 11, 324-330 (1951).

MacDonati, M.K., and J.T. IreLand: The Glomerular Lesion in Idiopathic and Secondary Diabetes. In Ciba Foundation Colloquia on Endocrinology, vol. 15: The Aetiology of Diabetes Mellitus and its Complications. Editors: Cameron, M.P. and M. O'Connor, J. \& A Churchill, LTD., London, 301-314 (1964).

Mériel, P., Ch. Darnadd, Y. Dengard, G. Morfau, J.M. Suo, J. Putors, and P.F. Combes: La glomérulose diabétique: étude ultra-structurale. La Presse Médicale 70, 667-670 (1962).

Rosenbaum, P., A.A. Kattine, and W.L. Gottsegen: Diabetic and Prediabetic Nephropathy in Chilhood. Am. J. Diseases of Children, 106, 83-95 (1963).

Sabour, M.S., M.K. MacDonato, and J.S. Robson: An Electron Microscopic Study of the Human Kidney in Young Diabetic Patients with Normal Renal Function. Diabetes 11, 291-295 (1962).

Dr. Ruth Østerby HANSEN University Institute of Pathology Kommunehospitalet

Århus/Denmark 